\title{
Multiple Regression for the Schistosomiasis Positivity Index Estimates in the Minas Gerais State - Brazil at Small Communities and Cities Levels
}

\author{
Ricardo J.P.S. Guimarães, Corina C. Freitas, \\ Luciano V. Dutra, Guilherme Oliveira and \\ Omar S. Carvalho \\ Additional information is available at the end of the chapter \\ http://dx.doi.org/10.5772/53500
}

\section{Introduction}

Schistosomiasis, caused by Schistosoma mansoni, is an endemic disease conditional on the presence of snails of aquatic habits of the genus Biomphalaria.

In Brazil, there are eleven species and one subspecies of Biomphalaria genus mollusks that have been identified: B. glabrata (Say, 1818), B. tenagophila (Orbigny, 1835), B. straminea (Dunker, 1848), B. peregrina (Orbigny, 1835), B. schrammi (Crosse, 1864), B. kuhniana (Clessin, 1883), B. intermedia (Paraense \& Deslandes 1962), B. amazonica (Paraense 1966), B. oligoza (Paraense 1974), B. occidentalis (Paraense 1981), B. cousini (Paraense, 1966) and B. tenagophila guaibensis (Paraense 1984) [1].

In Minas Gerais state, the presence of seven species: B. straminea, B. tenagophila, B. peregrina, B. schrammi, B. intermedia and B. occidentalis was reported [1]. Among these, there are three Biomphalaria species (B. glabrata, B. tenagophila and B. straminea) that have been found to be naturally infected with S. mansoni. Other three species, B. amazonica, B. peregrina and B. cousini, were experimentally infected, being considered as potential hosts of this trematode [2-4]. B. glabrata is of great importance, due to its extensive geographic distribution, high infection indices and efficiency in the schistosomiasis transmission. In endemic areas, large concentrations of these snails, together with other risk factors, favor the existence of localities with high prevalence [5-7]. 
The snails of the Biomphalaria genus live in a wide range of habitats, particularly in shallow and slow running waters and with floating or rooted vegetation. As these snails are distributed over large geographic areas and their populations are adapted to different environmental conditions, they can tolerate large variations in physical, chemical and biological environment in which they live $[8,9]$.

The intermediate hosts' distribution of the parasite in Minas Gerais associated with favorable eco-epidemiological conditions gives the schistosomiasis expansive character not seen even in non-endemic regions $[6,10,11]$.

Public health and the environment are influenced by the patterns of space occupation. Therefore, the use of geoprocessing techniques to analyze the spatial distribution of health problems allows one to determine local risks and delimit areas that concentrate the most vulnerable situations (occurrence of disease, characteristics of the environment and habitat of the intermediate host / vector). It is also possible with the use of geographic information systems to plan, schedule, control, monitor, and evaluate the diseases in groups according to their risk of transmission [12].

The use of Geographic Information Systems (GIS) and statistical tools in health has been facilitated by access to epidemiological data bases, enabling the production of thematic maps that contribute to the formulation of hypotheses about the spatial distribution of diseases and their relation to the socioeconomic variables [13].

The use of GIS and Remote Sensing (RS) are powerful tools for working complex analysis of a large number of information and viewing the results of this analysis in graphical maps. Since the seventies, RS has been applied to social sciences and health [14]. There are numerous information collected by RS data, describing some biotic and abiotic factors [15]. Application of RS and GIS techniques for mapping the risk of parasitic diseases, including schistosomiasis, has been performed over the past 15 years [16].

The estimate of schistosomiasis prevalence using GIS was first used in the Philippines and the Caribbean by [17, 18]. In Brazil, the use of GIS in schistosomiasis was first used by [19] in the state of Bahia. The authors constructed maps with environmental characteristics (total precipitation for three consecutive months, the annual maximum and minimum temperature and diurnal temperature differences), prevalence of S. mansoni and distribution of snails to study the spatial and temporal dynamics of infection and identify the environmental factors that influence the distribution of schistosomiasis. The results indicated that the snail population density and duration of annual dry season are the most important determinants for the prevalence of schistosomiasis in the study areas.

Table 1 shows a brief history of the use of GIS techniques in the study of schistosomiasis in several countries.

The main objective of the present study is to establish a relationship between schistosomiasis positivity index and the environmental and socioeconomic variables, in the Minas Gerais State, Brazil, using multiple linear regressions at small communities and cities levels. 


\begin{tabular}{|c|c|c|c|c|c|}
\hline Vector & Species & Study Area & Satellite-sensor & Technical-variables & Reference \\
\hline - & $\begin{array}{l}\text { Schistosoma } \\
\text { spp }\end{array}$ & $\begin{array}{l}\text { Philippines, th } \\
\text { Caribbean }\end{array}$ & eLandsat (MSS) & climate & {$[17,18]$} \\
\hline Oncomelania spp & $\begin{array}{l}\text { Schistosoma } \\
\text { spp }\end{array}$ & China & $\begin{array}{l}\text { NOAA (AVHRR), Lansdat } \\
\text { (TM) }\end{array}$ & ecological zones & [20] \\
\hline $\begin{array}{l}\text { B. truncatus, } \\
\text { B. alexandrina }\end{array}$ & $\begin{array}{l}\text { S. mansoni, } \\
\text { S. } \\
\text { haematobium }\end{array}$ & Egypt & NOAA (AVHRR) & temperature, NDVI & [21] \\
\hline $\begin{array}{l}\text { Phlebotomus } \\
\text { papatasi }\end{array}$ & $\begin{array}{l}\text { Schistosoma } \\
\text { spp }\end{array}$ & Southeast Asi & NOAA (AVHRR) & NDVI & [22] \\
\hline B. straminea & S.mansoni & Brazil & - & spatial distribution & [23] \\
\hline B. pfeifferi & S.mansoni & Kenya & - & $\begin{array}{l}\text { linear regression, mapping } \\
\text { techniques, cluster analysis }\end{array}$ & {$[24]$} \\
\hline B. alexandrina & $\begin{array}{l}\text { S. mansoni, } \\
\text { S. } \\
\text { haematobium }\end{array}$ & Egypt & $\begin{array}{l}\text { NOAA (AVHRR), Lansdat } \\
\text { (TM) }\end{array}$ & $\mathrm{dT}, \mathrm{NDVI}, \mathrm{MDE}$ & [25] \\
\hline $\begin{array}{l}\text { B. glabrata, } B \text {. } \\
\text { straminea, } B \text {. } \\
\text { tenagophila }\end{array}$ & S.mansoni & Brazil & - & $\begin{array}{l}\text { temperature, precipitation, } \\
\text { DEM, soil type, vegetation } \\
\text { type }\end{array}$ & [19] \\
\hline Oncomelania spp & $\begin{array}{l}\text { Schistosoma } \\
\text { spp }\end{array}$ & China & Landsat (TM) & classification, GIS & [26] \\
\hline $\begin{array}{l}\text { Bulinus spp, } \\
\text { Biomphalaria sp }\end{array}$ & $\begin{array}{l}\text { S. mansoni, } \\
\text { S. } \\
\text { haematobium }\end{array}$ & Tanzania & - & GIS, logistic regression & [27] \\
\hline B. alexandrina & S. mansoni & Egypt & $\begin{array}{l}\text { NOAA (AVHRR), Lansdat } \\
\text { (TM) }\end{array}$ & $d T, B E D, N D V I$ & [28] \\
\hline $\begin{array}{l}\text { B. glabrata, } B \text {. } \\
\text { straminea }\end{array}$ & S. mansoni & Brazil & NOAA (AVHRR) & NDVI, dT & [29] \\
\hline Bulinus spp & $\begin{array}{l}\text { S. } \\
\text { haematobium }\end{array}$ & Tanzania & NOAA (AVHRR) & $\begin{array}{l}\text { LST, NDVI, DEM, } \\
\text { precipitation, logistic } \\
\text { regression }\end{array}$ & [30] \\
\hline B. pfeifferi & S. mansoni & Ethiopia & NOAA (AVHRR) & LST, NDVI & [31] \\
\hline B. pfeifferi & S. mansoni & Ethiopia & NOAA (AVHRR) & $\begin{array}{l}\text { NDVI, temperature, logistic } \\
\text { regression }\end{array}$ & [32] \\
\hline Oncomelania spp & S. japonicum & China & $\begin{array}{l}\text { NOAA (AVHRR), Lansdat } \\
\text { (TM) }\end{array}$ & TNDVI & [33] \\
\hline- & $\begin{array}{l}\text { Schistosoma } \\
\text { spp }\end{array}$ & $\begin{array}{l}\text { Chad, } \\
\text { Cameroon }\end{array}$ & NOAA (AVHRR) & ecology & [34] \\
\hline
\end{tabular}




\begin{tabular}{|c|c|c|c|c|c|}
\hline Vector & Species & Study Area & Satellite-sensor & Technical-variables & Reference \\
\hline $\begin{array}{l}\text { B. pfeifferi, } B \text {. } \\
\text { senegalensis }\end{array}$ & $\begin{array}{l}\text { S. mansoni, } \\
\text { S. } \\
\text { haematobium }\end{array}$ & $\begin{array}{l}\text { Africa (sub- } \\
\text { Saharan } \\
\text { Africa) }\end{array}$ & NOAA (AVHRR) & SIG & [35] \\
\hline - & $\begin{array}{l}\text { S. } \\
\text { haematobium }\end{array}$ & Chad & - & environmental data & [36] \\
\hline - & $\begin{array}{l}\text { S. mansoni, } \\
\text { S. } \\
\text { haematobium }\end{array}$ & Cameroon & NOAA (AVHRR), EROS & logistic regression & [37] \\
\hline Oncomelania spp & $\begin{array}{l}\text { Schistosoma } \\
\text { spp }\end{array}$ & China & Landsat (TM) & RS & [38] \\
\hline $\begin{array}{l}\text { Oncomelania } \\
\text { hupensis }\end{array}$ & S. japonicum & China & Landsat (TM) & LU & [39] \\
\hline $\begin{array}{l}\text { Oncomelania spp, } \\
\text { Bulinus spp, } \\
\text { Biomphalaria spp }\end{array}$ & $\begin{array}{l}\text { S. japonicum, } \\
\text { S. mansoni, } \\
\text { S. } \\
\text { haematobium }\end{array}$ & China & Landsat (TM) & SIG & [40] \\
\hline $\begin{array}{l}\text { Oncomelania } \\
\text { hupensis }\end{array}$ & S. japonicum & China & Lansdat (TM) & TNDVI & [41] \\
\hline Bulinus spp. & $\begin{array}{l}\text { S. } \\
\text { haematobium }\end{array}$ & Kenya & NOAA (AVHRR) & Tmax & [42] \\
\hline B. glabrata & S. mansoni & Brazil & - & GPS & [43] \\
\hline - & $\begin{array}{l}\text { S. mansoni, } \\
\text { S. } \\
\text { haematobium }\end{array}$ & Uganda & Landsat (TM) & ecological zones & [44] \\
\hline - & $\begin{array}{l}\text { Schistosoma } \\
\text { spp }\end{array}$ & Uganda & NOAA (AVHRR) & LST & [45] \\
\hline $\begin{array}{l}\text { Oncomelania } \\
\text { hupensis }\end{array}$ & S. japonicum & Japan & - & PDA & {$[46]$} \\
\hline $\begin{array}{l}\text { Oncomelania } \\
\text { hupensis }\end{array}$ & S. japonicum & China & Ikonos, ASTER & MDE & [47] \\
\hline - & S. mansoni & Côte d'Ivoire & $\begin{array}{l}\text { Landsat (ETM), NOAA } \\
\text { (AVHRR), EROS, MODIS }\end{array}$ & $\begin{array}{l}\text { environmental and } \\
\text { socioeconomic data }\end{array}$ & {$[16,48]$} \\
\hline O. hupensis & S. japonicum & China & Landsat (TM) & NDVI & [49] \\
\hline $\begin{array}{l}\text { Oncomelania } \\
\text { hupensis }\end{array}$ & S. japonicum & China & NOAA (AVHRR) & LST & [50] \\
\hline $\begin{array}{l}\text { Oncomelania } \\
\text { hupensis }\end{array}$ & S. japonicum & China & Landsat (TM) & SAVI & [51] \\
\hline
\end{tabular}




\begin{tabular}{|c|c|c|c|c|c|}
\hline Vector & Species & Study Area & Satellite-sensor & Technical-variables & Reference \\
\hline- & S. mansoni & Brazil & - & $\begin{array}{l}\text { logistic regression models } \\
\text { and Bayesian spatial models }\end{array}$ & [52] \\
\hline Biomphalaria sp & S.mansoni & Brazil & MODIS, SRTM & $\begin{array}{l}\text { regression, elevation, mixture } \\
\text { model, NDVI }\end{array}$ & {$[53]$} \\
\hline B. glabrata & S.mansoni & Brazil & - & $\begin{array}{l}\text { spatial analysis, GPS, } \\
\text { immunological data }\end{array}$ & [54] \\
\hline Biomphalaria sp & S.mansoni & Brazil & - & $\begin{array}{l}\text { social and environmental } \\
\text { data, regression }\end{array}$ & {$[55]$} \\
\hline Biomphalaria spp & S. mansoni & Brazil & - & GPS and GIS & {$[56]$} \\
\hline B. glabrata & S. mansoni & Brazil & - & kernel & [57] \\
\hline- & $\begin{array}{l}\text { Schistosoma } \\
\text { spp }\end{array}$ & Africa & - & ecology, GIS, RS, geostatistics & [58] \\
\hline B. pfeifferi & S. mansoni & Côte d'Ivoire & - & $\begin{array}{l}\text { socioeconomic data, logistic } \\
\text { regression, Bayesian model }\end{array}$ & [59] \\
\hline $\begin{array}{l}\text { B. sudanica, } B \text {. } \\
\text { stanleyi }\end{array}$ & S. mansoni & Uganda & - & spatial analysis & {$[60]$} \\
\hline- & $\begin{array}{l}\text { S. } \\
\text { haematobium }\end{array}$ & Tanzania & - & $\begin{array}{l}\text { social and ecological data, } \\
\text { Bayesian models, logistic } \\
\text { regression, NDVI, elevation, } \\
\text { cluster analysis }\end{array}$ & {$[61]$} \\
\hline Biomphalaria sp & S.mansoni & Brazil & MODIS, SRTM & $\begin{array}{l}\text { social and environmental } \\
\text { data, RS, NDVI, temperature, } \\
\text { regression }\end{array}$ & {$[62]$} \\
\hline Biomphalaria sp & S.mansoni & Brazil & MODIS, SRTM & $\begin{array}{l}\text { linear regression, imprecise } \\
\text { classification, regionalization } \\
\text { and pattern recognition }\end{array}$ & [63] \\
\hline $\begin{array}{l}\text { Oncomelania } \\
\text { hupensis }\end{array}$ & S. japonicum & China & SPOT & $\begin{array}{l}\text { ecological data, land use, } \\
\text { land cover, classification, } \\
\text { Bayesian model, RS, NDVI, } \\
\text { slope, LST }\end{array}$ & {$[64]$} \\
\hline- & $\begin{array}{l}\text { Schistosoma } \\
\text { spp }\end{array}$ & China & - & $\begin{array}{l}\text { GIS, spatial analysis and } \\
\text { clustering, Bayesian model, }\end{array}$ & {$[65]$} \\
\hline- & $\begin{array}{l}\text { S. mansoni, } \\
\text { S. } \\
\text { haematobium }\end{array}$ & Mali & NOAA (AVHRR) & $\begin{array}{l}\text { Bayesian models, NDVI, LST, } \\
\text { GIS, logistic regression }\end{array}$ & {$[66]$} \\
\hline Biomphalaria sp & S.mansoni & Brazil & - & kriging, spatial distribution & {$[67,68]$} \\
\hline Biomphalaria sp & S.mansoni & Brazil & - & Fuzzy logic & [69] \\
\hline
\end{tabular}




\begin{tabular}{|c|c|c|c|c|c|}
\hline Vector & Species & Study Area & Satellite-sensor & Technical-variables & Reference \\
\hline- & S. japonicum & China & - & $\begin{array}{l}\text { GIS, spatial analysis, } \\
\text { clustering, kernel }\end{array}$ & {$[70]$} \\
\hline Biomphalaria sp & S. mansoni & Brazil & MODIS & $\begin{array}{l}\text { meteorological data, } \\
\text { socioeconomic, sanitation, } \\
\text { RS, regression }\end{array}$ & [71] \\
\hline B. straminea & S.mansoni & Brazil & - & $\begin{array}{l}\text { kernel, GPS, spatial } \\
\text { distribution }\end{array}$ & {$[72]$} \\
\hline B. glabrata & S.mansoni & Brazil & MODIS & mixture model & [73] \\
\hline Biomphalaria sp & S.mansoni & Brazil & MODIS, SRTM & $\begin{array}{l}\text { social and environmental } \\
\text { data, sanitation, biological, } \\
\text { RS, NDVI, temperature, } \\
\text { regression, kriging }\end{array}$ & {$[1,74]$} \\
\hline Biomphalaria sp & S.mansoni & Brazil & MODIS & $\begin{array}{l}\text { decision tree, environmental } \\
\text { data, RS }\end{array}$ & [75] \\
\hline- & $\begin{array}{l}\text { S. mansoni, } \\
\text { S. } \\
\text { haematobium }\end{array}$ & East Africa & - & $\begin{array}{l}\text { Bayesian geostatistics, logistic } \\
\text { regression, Markov chain } \\
\text { Monte Carlo simulation, }\end{array}$ & $c[76]$ \\
\hline Biomphalaria sp & S.mansoni & Africa & MODIS & $\begin{array}{l}\text { Climate change, spatial } \\
\text { distribution, temperature, } \\
\text { precipitation, MaxEnt, soil }\end{array}$ & [77] \\
\hline- & S.mansoni & $\begin{array}{l}\text { Ethiopia, } \\
\text { Kenya }\end{array}$ & NOAA (AVHRR) & $\begin{array}{l}\text { geostatistics, LST, NDVI, } \\
\text { elevation, environmental } \\
\text { data, LQAS, LpCP }\end{array}$ & [78] \\
\hline Biomphalaria spp & S. mansoni & Brazil & - & GPS, GIS, spatial distribution & [79] \\
\hline
\end{tabular}

Table 1. Use of geoprocessing techniques in the study of schistosomiasis.

\section{Material and methods}

\subsection{Materials}

The study area includes 4,846 small communities (called localities) in the entire State of Minas Gerais, Brazil. The dependent variable is the schistosomiasis positivity index (Ip). Ip were obtained from the Brazilian Schistosomiasis Control Program (PCE) through the annual reports of the Secretary of Public Health Surveillance (SVS) and the Secretary of Health in the State of Minas Gerais (SESMG). From the 4,846 locations mentioned above, only 1,590 of them have information on the positivity of the disease. Since schistosomiasis is a disease characterized by environmental and social factors, environmental and socioeconomic varia- 
bles were used as explanatory variables, as well as a variable containing information about presence of intermediate hosts. A brief description of these variables is given below.

\subsection{Schistosomiasis positivity index}

Schistosomiasis positivity index (Ip) values were obtained in 1,590 localities from the Brazilian Schistosomiasis Control Program (PCE) through the Annual Reports of the Secretary of Public Health Surveillance (SVS) and the Secretary of Health in the State of Minas Gerais (SESMG). The Ip data were obtained from the database SISPCE (Information System of the Brazilian Schistosomiasis Control Program) from 1996 to 2009. The Kato-Katz technique is the methodology used to determine positivity index, examining one slide per person.

These I $p$ were determined for each locality $i$ by:

$$
I p=\frac{r_{i}}{n_{i}} * 100
$$

where: $r_{i}$ is the number of infected people and $n_{i}$ is the total population in locality $i$.

\subsection{Intermediate hosts}

Information about the existence of Biomphalaria snails were provided at a municipality basis by the Laboratory of Helminthiasis and Medical Malacology of the Rene Rachou Research Center (CPqRR/Fiocruz-MG).

The distribution of Biomphalaria snails used for this study was defined as: B. glabrata, B. tenagophila, B. straminea, B. glabrata + B. tenagophila, B. glabrata + B. straminea, B. tenagophila + B. straminea, B. glabrata + B. tenagophila + B. straminea and No Biomphalaria. The class "No Biomphalaria" includes information about the non-occurrence of Biomphalaria species or information about non-transmitter species in Brazil, such as B. peregrina, B. schrammi, B. intermedia, B. occidentalis, etc.

The spatial distribution of the schistosomiasis Ip and the Biomphalaria species data are presented in Fig. 1.

\subsection{Environmental data}

Twenty eight environmental variables were obtained from remote sensing and meteorological sources.

The remote sensing variables were derived from Moderate Resolution Imaging Spectroradiometer (MODIS) and from the Shuttle Radar Topography Mission (SRTM) sensor.

The variables of MODIS sensor used were collected in two seasons, summer (from 17/Jan/ 2002 to 01/Feb/2002 period) and winter (from 28/Jul/2002 to 12/Aug/2002 period). MODIS data were composed by the blue, red, near and middle infrared bands and also the vegetation indices (NDVI and EVI) [73]. 


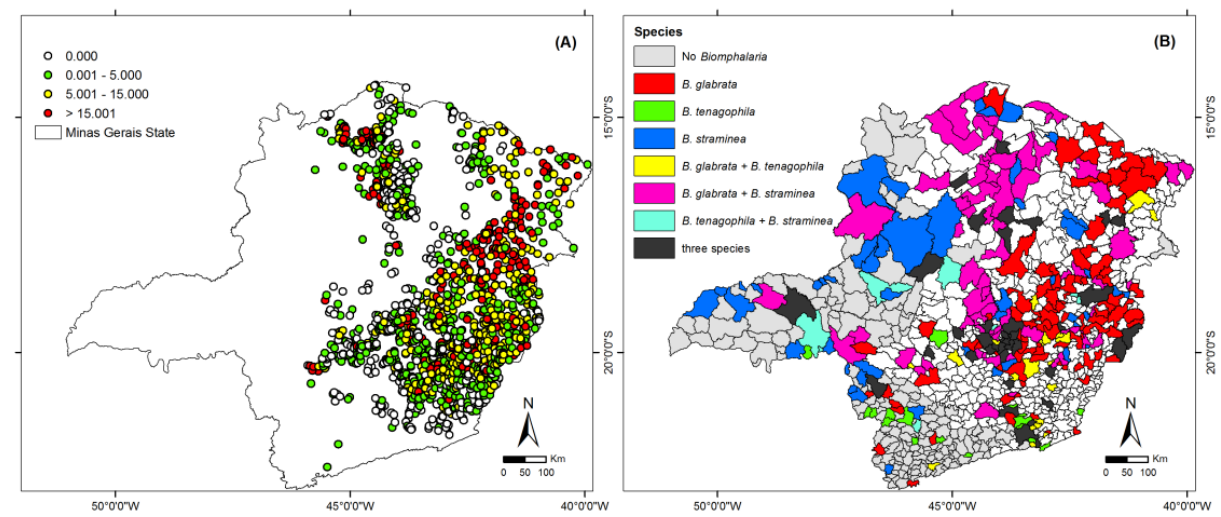

Figure 1. Spatial distribution of the (a) schistosomiasis and (b) Biomphalaria species in Minas Gerais State, Brazil.

The Linear Spectral Mixture Model (LSMM) is an image processing algorithm that generates fraction images with the proportion of each component (vegetation, soil, and shade) inside the pixel, which is estimated by minimizing the sum of square of the errors. In this work, the so called vegetation, soil, and shade fraction images were generated using the MODIS data, and the estimated values for the spectral reflectance components were also used as an input to the regression models [73].

Others variables obtained from SRTM were also used in this study: the digital elevation model (DEM) and slope (derived from DEM). Based on the SRTM data, a drainage map of Minas Gerais was generated, and the variables: water percentage in municipality (QTA) and water accumulation (WA) were derived. Six meteorological variables consisting of total precipitation (Prec), minimum (Tmin) and maximum (Tmax) temperature average for summer and winter seasons were obtained from the Center for Weather Forecast and Climate Studies (CPTEC), in the same date of MODIS images.

\subsection{Socioeconomic data}

Socioeconomic variables obtained by The Brazilian Institute of Geography and Statistics (IBGE) census for the year 2000 were also used as explanatory variables. The variables used in this work are those related to the water quality (percentage of domiciles with access to the general net of water supply, access to the water through wells or springheads, and with other access forms to the water), and to the sanitary conditions (the percentage of domiciles with bathroom connected to rivers or lakes, connected to a ditch, to rudimentary sewage, to septic sewage, to a general net, to other sewerage type, with bathroom or sanitarium and without bathroom or sanitarium).

\subsection{Methods}

Indicator kriging and multiple linear regressions were employed to estimate the presence of the intermediate host and the schistosomiasis disease, respectively. 


\subsection{Indicator Kriging}

Since information about existence of Biomphalaria is only available on municipality basis, indicator kriging was used in this study to make inferences, in a grid basis, about the presence of the Biomphalaria species (B. glabrata, B. tenagophila and/or B. straminea), intermediate hosts of $S$. mansoni. The method allows spatialization of the data conditioned to the sample set of categorical attributes, aiming at the spatial distribution and production of maps.

The categorical attributes (classes) used for this study were defined as: B. glabrata, $B$. tenagophila, B. straminea, B. glabrata + B. tenagophila, B. glabrata + B. straminea, B. tenagophila + B. straminea, B. glabrata + B. tenagophila + B. straminea and No Biomphalaria totalizing eight probable classes.

The snail attributes (class of species and localization) were distributed along the drainage network of 15 River Basins (Buranhém, Doce, Grande, Itabapoana, Itanhém, Itapemirim, Jequitinhonha, Jucuruçu, Mucuri, Paraíba do Sul, Paranaíba, Pardo, Piracicaba/Jaguari, São Francisco and São Mateus), according to the methodology used by [67].

In [1], however the indicator kriging was used only at municipalities' level, but in this study it was used for localities level.

Indicator kriging procedures were applied to obtain an approximation of the conditional distribution function of the random variables. Based on the estimated function, maps of snail spatial distributions along with the corresponding uncertainties for the entire state and also map of estimated prevalence of schistosomiasis were built.

The indicator kriging result was used as a variable in multiple regression models.

\subsection{Multiple linear regressions}

Multiple linear regressions are a form of regression analysis in which data are modeled by a least squares function which is a linear combination of the model parameters and depends on one or more independent variables.

The regression analysis was applied with the schistosomiasis Ip as dependent variable, in addition to 93 quantitative variables (28 environmental variables and 65 socioeconomic variables), and one qualitative variable resulting from the kriging (presence or absence of $B$. glabrata) as explanatory variables.

The dependent variable was randomly divided into two sets: one with 852 cases (localities) for variables selection and model definition, and another with 738 cases for model validation.

Due to the high number of independent variables, some procedures were performed for variables selection. The relations among the dependent and the independent variables were analyzed in terms of correlation, multi co-linearity, and possible transformations that better explain the dependent variable.

A logarithmic transformation for the dependent variable (denoted by $\ln I p$ ) was made as it improved the correlation with independent variables. 
The analysis of the correlation matrix showed that some variables had non-significative correlations with $\operatorname{lnI} p$ at $95 \%$ confidence level, and also some variables were highly correlated among themselves, indicating that those variables could be excluded from future analysis.

Since multi co-linearity effects among the remaining independent variables were detected, variables selection techniques were used in order to choose a set of variables that better explain the dependent variable. Variable selection was performed by the $\mathrm{R}^{2}$ criterion using all possible regressions [80].

This selection technique consists in the identification of a best subset with few variables and a coefficient of determination $\mathrm{R}^{2}$ sufficiently close to that when all variables are used in the model.

Interaction effects were also analyzed to be included in the model. After performing the residual analysis, the chosen regression model was then validated. The final estimated regression function was computed using the entire data set (definition and validation), and it was applied to all localities to build a risk map for schistosomiasis positivity index.

The multiple regressions were developed based on two approaches: a global model (throughout the state) and a regional model (regionalization).

Regionalization is a classification procedure using the SKATER algorithm (Spatial 'K'luster Analysis by Tree Edge Removal) applied to spatial objects with an areal representation (municipalities), which groups them into homogeneous contiguous regions [81].

Regionalization was applied in Minas Gerais to divide the state into four homogeneous regions. The choice of the number of regions was based on the spatial distribution of localities (Figure 1b) in order to achieve an adequate number of localities in each region.

The regional model was developed by doing a regression model separately in each of the four regions formed by first applying the SKATER algorithm using environmental variables [74].

The models validation was performed using the Root Mean Square Error (RMSE) and the Mean Squared Prediction Error (MSPR), given by [80].

$$
R M S E=\sqrt{\frac{\sum_{i=1}^{n}\left(I p_{i}-\hat{I} p_{i}\right)^{2}}{n}}
$$

where $I p_{i}$ and $\hat{I} p_{i}$ represent, respectively, the observed and predicted positivity index in the $i$-th observation and $n$ is the number of observations of the data model definition $(i=1, \ldots, n)$.

The RMSE measures the variation of the observed values around the estimated values. Ideally, the values of RMSE are close to zero. The MSPR is computed the same way as the RMSE, but using validation samples.

The final models were applied in all 4,846 localities to estimate the positivity index. 


\subsection{Simple average interpolator}

The simple average interpolator (SAI) algorithm of the software SPRING [82] was used to estimate the value of $I p$ at each point $(x, y)$ of the grid. This estimative is based on the simple average of the variable values in the eight nearest neighbors of this point, according to equation (3).

$$
f(x, y)=\frac{1}{8}\left(\sum_{i=1}^{8} \hat{I} p_{i}\right)
$$

where $\hat{I} p_{i}$ is the estimated positivity index of the 8 neighbors of the point $(x, y)$ and $f(x, y)$ is the interpolation function.

The file generated by interpolation was a grid with spatial resolution of $1 \mathrm{~km}$. The purpose of using this tool was to determine which of the mesoregions presented estimated values above $15 \%$ (class with high positivity index).

\section{Results and discussion}

The GeoSchisto Database (http://www.dpi.inpe.br/geoschisto/) was created containing all variables used in this study.

The indicator kriging result was a regular grid of $250 \times 250$ meters with the estimate of Biomphalaria species class for the entire Minas Gerais State. The indicator kriging result is presented in Fig. 2a. The variable B. glabrata used in regression models is presented in Fig. 2b.
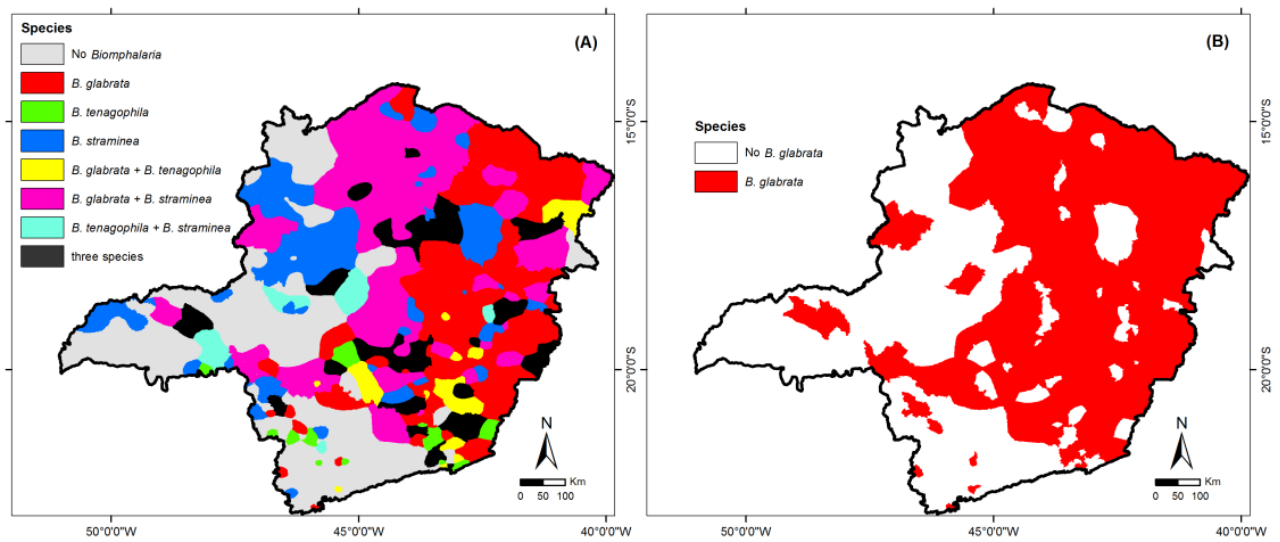

Figure 2. a) Kriging and (b) estimated presence of B. glabrata by indicator kriging. 


\subsection{Global model}

The five variables selected were: presence or absence of the B. glabrata, summer precipitation $\left(P C_{s}\right)$, summer minimum temperature $\left(T N_{s}\right)$, winter Enhanced Vegetation Index $\left(E V I_{w}\right)$ and households with a bathroom or toilet and sewage from septic tank type $\left(V_{31}\right)$.

The final model, with $\mathrm{R}^{2}=0.18$, was:

$$
\widehat{I} p=e^{\left(-7.34+0.51 B G+0.004 P C_{s}+0.37 T N_{s}+0.0003 E V I_{w w}+0.004 V_{31}\right)}-1
$$

Fig. 3a shows the estimated I $p$ for all 4,842 localities in Minas Gerais using the estimated regression equation (4). Figure $3 \mathrm{~b}$ shows the plot of the residuals, resulting from the difference between observed and estimated I $p$ from 1,590 locations. In Figure 3b, dark colors (red and blue) represent overestimated values, light colors (red and blue) underestimated ones, and in white are the municipalities where the estimated prevalence differs very little from the true values.

The precipitation, minimum temperature, EVI and sanitation were positively correlated with $I p$. This is consistent with the adequate environmental conditions for the transmission of schistosomiasis. Also, the transmission depends on the presence of B. glabrata.

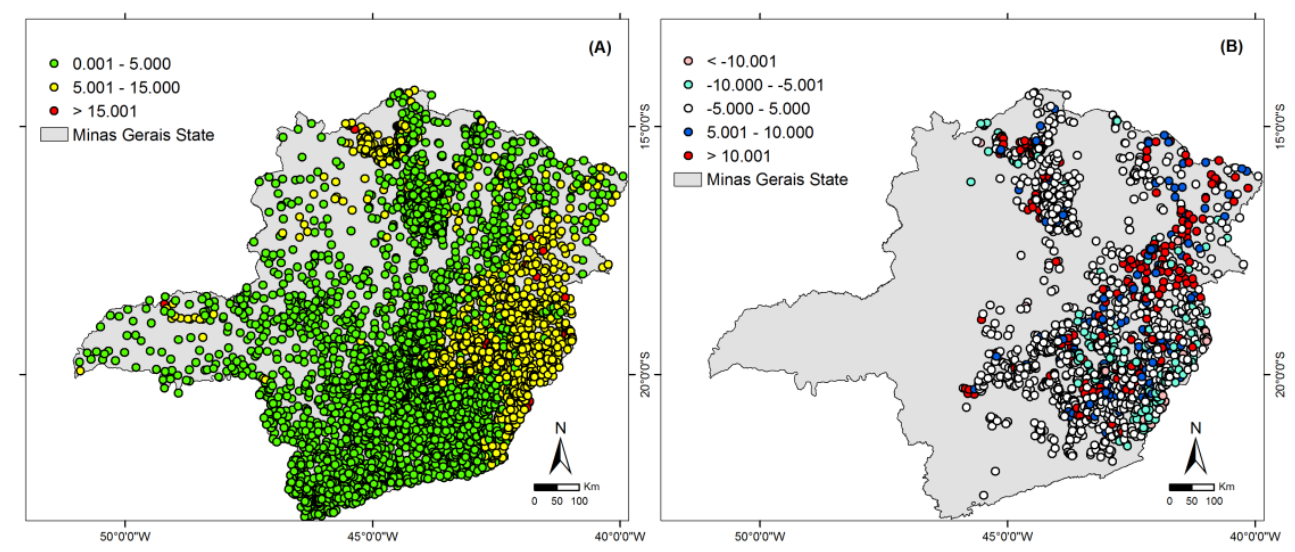

Figure 3. Global model: (a) estimated Ip and (b) residuals.

The result of this model has the same variables $\left(B G, T N_{s}, E v i_{w}\right.$ and sanitation) obtained by [74] when estimatives were done on a municipality basis, indicating a great similarity between the two global models. The difference is in the sanitation variable where the variable obtained by [74] was related to the type of water (well or spring) and this study to the type of sewage system (septic tank). 


\subsection{Regional model}

The Minas Gerais State was divided into four regions using the SKATER algorithm. Table 2 presents the number of localities in each region used for model generation and for model validation. The regionalization can be seen in Figure 4 a.

\begin{tabular}{cccc}
\hline & Model Generation & Model Validation & Total \\
\hline Region 1 (R1) & 104 & 66 & 170 \\
\hline Region 2 (R2) & 428 & 262 & 690 \\
\hline Region 3 (R3) & 220 & 338 & 558 \\
\hline Region 4 (R4) & 100 & 72 & 172 \\
\hline Total & 852 & 738 & 1590 \\
\hline
\end{tabular}

Table 2. Number of localities in each region used for model generation and for model validation.

Regression models were developed for each of the four regions with the same 94 variables used in the global model, and the same selection procedure. Different numbers of variables were selected in each region to determine the best regression model.

The final models generated for each region (Fig. 4c) and their $\mathrm{R}^{2}$ were:

$$
\begin{gathered}
\widehat{I} p_{1}=e^{\left(14.04+0.05 P C_{w}+0.01 V_{25}-1.15 \Delta T_{s}\right)}-1 \Rightarrow R^{2}=0.35 \\
\widehat{I} p_{2}=e^{\left(-11.63+0.68 B G+0.59 T N_{s}+0.0004 E V I_{w}+0.03 V_{25}-0.005 V_{261}\right)}-1 \Rightarrow R^{2}=0.21 \\
\widehat{I} p_{3}=e^{\left(0.16+0.39 B G+0.0002 N D V I_{s}-0.015 V_{33}+0.002 V_{283}\right)}-1 \Rightarrow R^{2}=0.38 \\
\widehat{I} p_{4}=e^{\left(-3.54+0.0001 E V I_{s}+0.006 P C_{s}+0.16 T N_{s}+0.27 Q T A+0.0006 V_{254}+0.003 V_{272}\right)}-1 \Rightarrow R^{2}=0.22
\end{gathered}
$$

where: $P C_{W}$ (winter precipitation), $V_{25}$ (percentage of households with another form of access to water), $\Delta T_{S}$ (difference of summer maximum and minimum temperature), $B G$ (presence or not of the B. glabrata), $T N_{S}$ (summer minimum temperature), $E V I_{W}$ (winter Enhanced Vegetation Index), $V_{261}$ (percentage of residents in households with another form of water supply), $N D V I_{S}$ (summer Normalized Difference Vegetation Index), $V_{33}$ (percentage of housing with bathroom or toiled connected to a ditch), $V_{283}$ (percentage of households without bathrooms), $E V I_{S}$ (summer Enhanced Vegetation Index), $P C_{S}$ (summer precipitation), QTA (water percentage in municipality), $V_{254}$ (percentage of households with water supply network general) and $V_{272}$ (percentage of households without toilet or sanitation). 

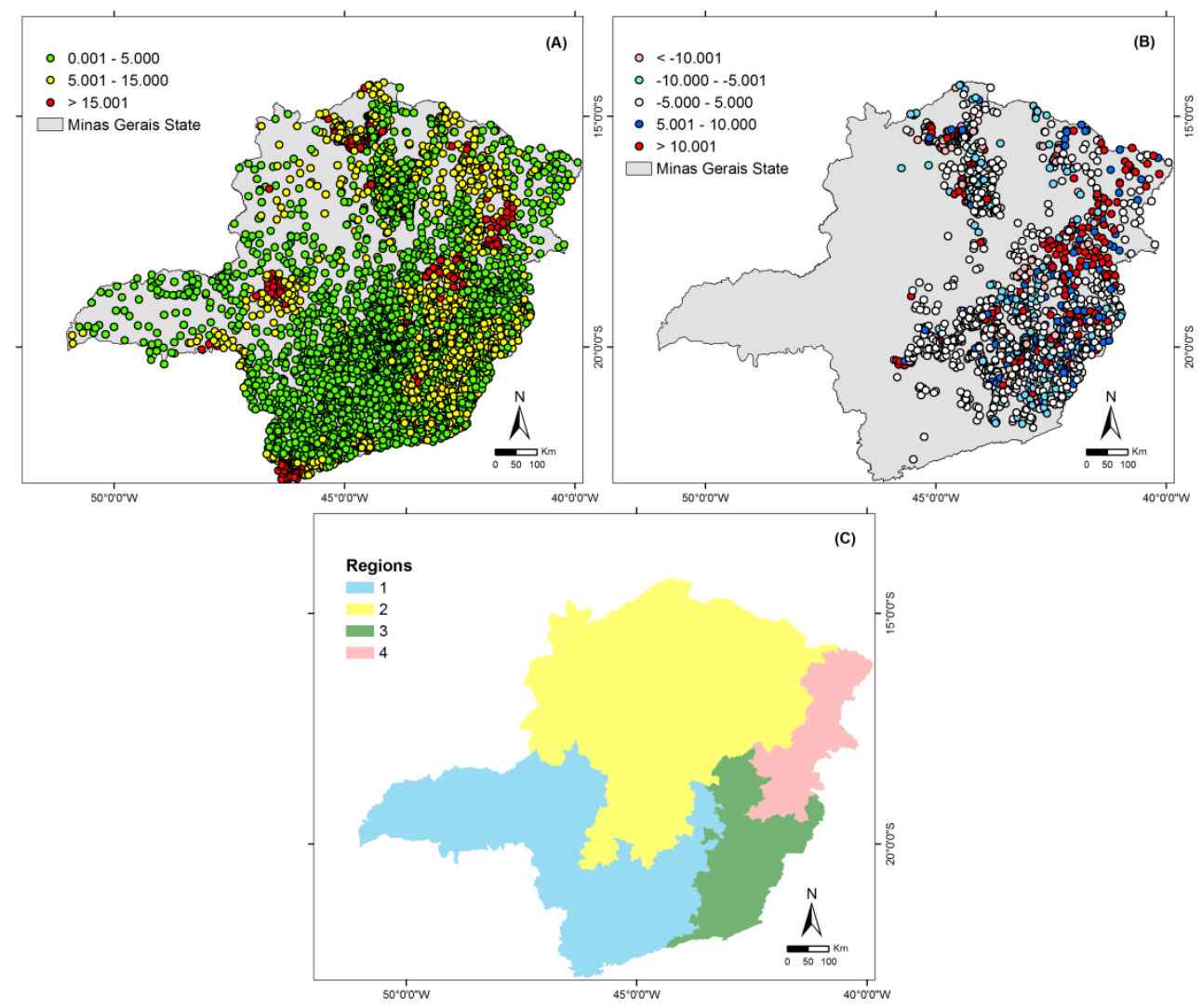

Figure 4. Regional model: (a) estimated $/ p$, (b) residuals. (c) regionalization.

Figure 4a shows the estimated values of Ip for all 4,842 localities in the Minas Gerais State using equations $(3,4,5$ and 6$)$. Also, Figure $4 \mathrm{~b}$ shows the residues from 1,590 locations. In this figure, red and blue represent overestimates, cyan and magenta represent the underestimated values and in the white localities with good estimate.

The regional model for Region $1\left(\mathrm{R}_{1}\right)$ reflects the effect of sanitation (households with other forms of water than tap water, wells or springs) and the influence of weather (precipitation and temperature of summer). Region 1 achieved a $\mathrm{R}^{2}$ value of 0.35 . The model obtained by [74] for the same Region 1 also has the same sanitation variable (percentage of homes with another type of access to water). The relationship between temperature and disease was also obtained by [29] and [55, 74].

The models for Regions 2 and $3\left(R_{2}\right.$ and $\left.R_{3}\right)$ show the presence of B. glabrata associated with the effect of vegetation $\left(E v i_{w}\right)$ and sanitation. Among the regional models, Region 2 had the lowest $R^{2}(0.21)$ and Region 3 had the highest $R^{2}(0.38)$. 
The model for Region $4\left(\mathrm{R}_{4}\right)$ shows that Ip was associated with vegetation $\left(E v i_{s}\right)$, weather (precipitation and temperature) and sanitation (type of water and sewage). The $\mathrm{R}^{2}$ found for this model was 0.22 .

In all models the presence of $B$. glabrata, sanitation, vegetation index and temperature were the most important variables. These characteristics are the same as environmental conditions for the presence and development of snails (infection of the intermediate host) and sanitation (water contamination - presence of S. mansoni cercariae) obtained by [74] which were obtained at municipalities level.

[29] also showed that the distribution of schistosomiasis in Bahia, at municipalities level, is related to the vegetation index $(N D V I)$ and temperature $(\triangle T s)$ using sensor data from low spatial resolution (AVHRR/NOAA).

\subsection{Simple Averages Interpolator (SAI)}

Table 3 presents the mean square error (RMSE) and Mean Squared Error of Prediction (MSPR) for the global and regional models, for each region. From this table we can observe that the mean square decreased from 10.739 to 9.979 when we used separate models for each region. It was also noted that the RMSE of the Regional Model was smaller than the RMSE of the Global Model for all four regions, highlighting the importance of using different equations and different variables for each region. Since the Regional Model can be considered a better model the Simple Averages Interpolator (SAI), was applied using the known positivity index of the 1,590 localities (Fig. 5a), and using the regression estimated positivity index of all 4,842 localities (Fig. 5b). The objective of applying SAI to all estimated I $p$ values is to indicate current and potential local transmission of schistosomiasis.

\begin{tabular}{|c|c|c|c|c|c|}
\hline & Model & $\mathrm{n}_{\text {RMSE }}$ & RMSE & $\mathrm{n}_{\mathrm{MSPR}}$ & MSPR \\
\hline \multirow{5}{*}{$\begin{array}{l}\bar{\pi} \\
\stackrel{O}{0} \\
\text { O }\end{array}$} & $\mathrm{R}_{1}$ & 104 & 8.078 & 66 & 3.421 \\
\hline & $\mathrm{R}_{2}$ & 428 & 12.369 & 262 & 11.741 \\
\hline & $\mathrm{R}_{3}$ & 220 & 10.042 & 338 & 10.048 \\
\hline & $\mathrm{R}_{4}$ & 100 & 6.164 & 72 & 8.282 \\
\hline & total & 852 & 10.739 & 738 & 10.145 \\
\hline \multirow{5}{*}{ 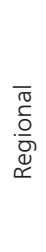 } & $\mathrm{R}_{1}$ & 104 & 7.576 & 66 & 3.376 \\
\hline & $\mathrm{R}_{2}$ & 428 & 11.553 & 262 & 11.577 \\
\hline & $\mathrm{R}_{3}$ & 220 & 9.044 & 338 & 9.538 \\
\hline & $\mathrm{R}_{4}$ & 100 & 6.123 & 72 & 8.291 \\
\hline & total & 852 & 9.979 & 738 & 9.848 \\
\hline
\end{tabular}

Table 3. Residual analysis of the dependent variable $(I p)$ for the models. 
Figure 5a shows clusters presence in six mesoregions (Norte de Minas, Jequitinhonha, Vale do Mucuri, Vale do Rio Doce, Metropolitana de Belo Horizonte and Zona da Mata) with the highest $I p$ values. In Figure $5 \mathrm{~b}$ the same six mesoregions can be noticed; however two news clusters in Sul/Sudoeste de Minas and Triângulo Mineiro/Alto Parnaíba mesoregions presented, respectively high and middle I $p$ values.
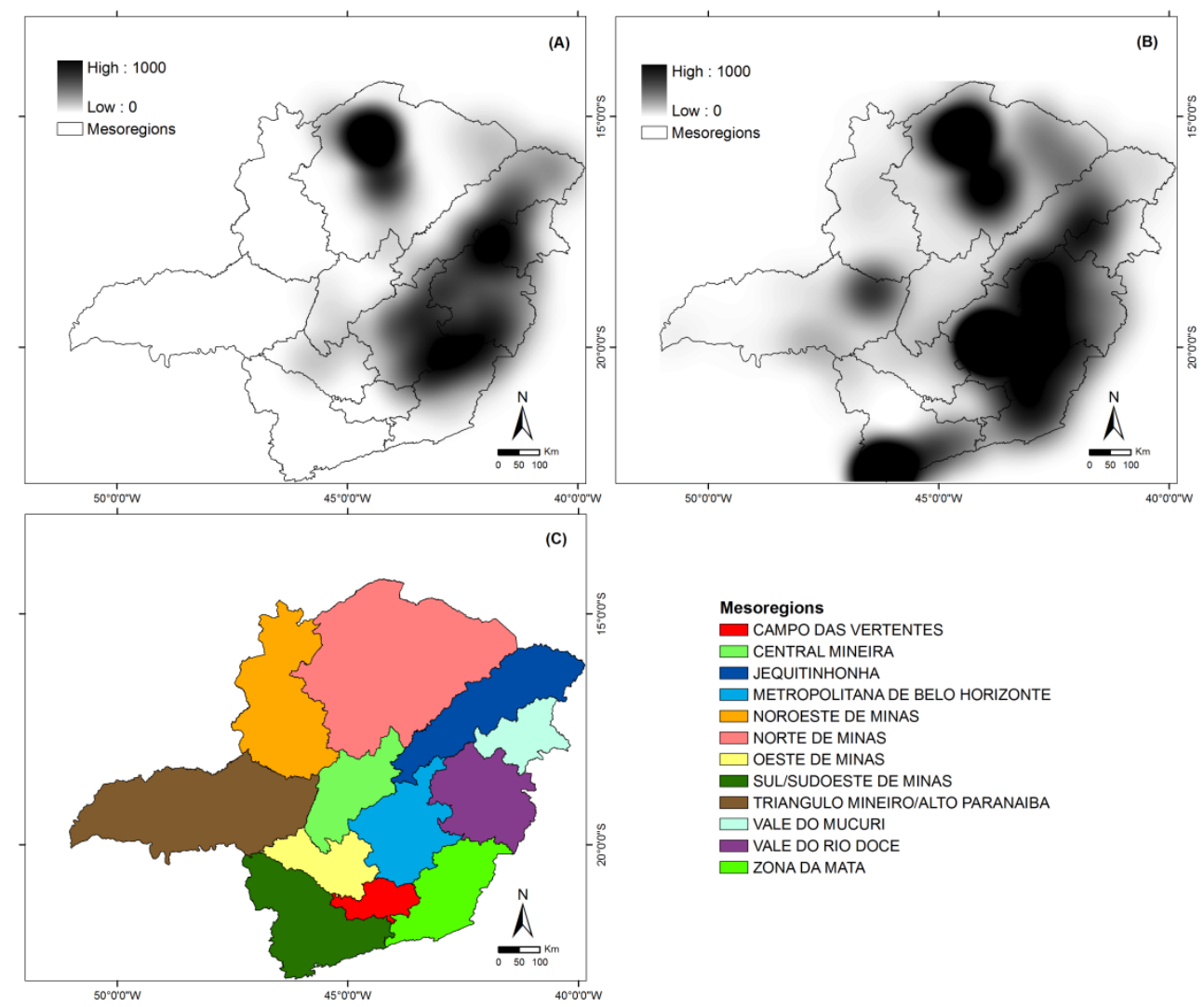

Figure 5. The averages interpolator: (a) Ip and (b) estimated Ip by Regional Model. (c) Mesoregions of Minas Gerais State.

Thus, the Norte de Minas, Jequitinhonha, Vale do Mucuri, Vale do Rio Doce, Metropolitana de Belo Horizonte and Zona da Mata mesoregions are endemics areas.

Sul/Sudoeste de Minas and Triângulo Mineiro/Alto Parnaíba mesoregions are not endemic areas, but have a schistosomiasis focus (Itajubá municipality in Sul mesoregion). The Sul/ Sudoeste de Minas mesoregion has 146 municipalities representing about 20\% of municipalities in Minas Gerais State and is a non-endemic area for schistosomiasis. Due to the high concentration of cities in an area of $49,523.893 \mathrm{~km}^{2}$ (which represents less than $10 \%$ of the 
area of Minas Gerais State) and a high agricultural economy, it is a region with high risk of schistosomiasis transmission. Therefore, it would be interesting to do a detailed study in the Sul mesoregion to determine the schistosomiasis I .

Also, it would be interesting to keep surveillance in the municipalities of the Triângulo Mineiro/Alto Parnaíba mesoregion that presented B. glabrata presence.

\section{Conclusions and future work}

This study shows the importance of a joint use of GIS and RS to study the risk of schistosomiasis. Moreover, it can be concluded that the combined use of GIS and statistical techniques allowed the estimation of schistosomiasis Ip. Results of the regression models confirmed the importance of the use of environmental variables to characterize the snail habitat in the endemic area of the state of Minas Gerais.

Results of the regression models show that regionalization improves the estimation of the disease in Minas Gerais. Based on this model, a schistosomiasis risk map was built for Minas Gerais. [74] and [75] also obtained a better model with the use of regionalization when estimating schistosomiasis at a municipality level.

The Simple Averages Interpolator is a technique that may indicate possible local to transmission and surveillance of schistosomiasis.

It is recommended the use of GPS for field surveys together and the application of this methodology with images of better spatial resolution $(10-30 \mathrm{~m})$ in other states for validation. Also, we recommend using a smaller area (municipality or mesoregion) estimate for the schistosomiasis.

The methodology used in this study can be utilized to control schistosomiasis in the areas with occurrence of the disease and also it can be used to take preventive measures to prevent the disease transmission.

Next step will be to utilize data from the PCE by localities to study other diseases such as ascariasis, hookworm, trichuriasis, etc, using data from CBERS and/or Landsat and new methodologies (Geographically Weighted Regression, Generalized Additive Model, etc).

\section{Acknowledgements}

The authors woud like to acknowledge the support of Sandra da Costa Drummond (Fundação Nacional de Saúde) and the support of CNPq (Conselho Nacional de Desenvolvimento Científico e Tecnológico) (grants \# 300679/2011-4, 384571/2010-7, 302966/2009-9, 308253/2008-6). 


\section{Author details}

Ricardo J.P.S. Guimarães ${ }^{1 *}$, Corina C. Freitas ${ }^{2}$, Luciano V. Dutra ${ }^{2}$, Guilherme Oliveira ${ }^{3}$ and Omar S. Carvalho ${ }^{3}$

*Address all correspondence to: ricardojpsg@gmail.com

1 Instituto Evandro Chagas/IEC, Ananindeua, Brazil

2 Instituto Nacional de Pesquisas Espaciais/INPE, São José dos Campos, Brazil

3 Centro de Pesquisas René Rachou/Fiocruz-MG, Belo Horizonte, Brazil

\section{References}

[1] Guimarães RJPS, Fonseca FR, Dutra LV, Freitas CC, Oliveira GC, Carvalho OS. A study of schistosomiasis prevalence and risk of snails presence spatial distributions using geo-statistical tools. In: MB R, (ed.). Schistosomiasis. Rijeka: InTech, 2012. p255-80.

[2] Correa LR, Paraense WL. Susceptibility of Biomphalaria amazonica to infection with two strains of Schistosoma mansoni. Rev Inst Med Trop São Paulo. 1971;13 387-90.

[3] Paraense WL, Correa LR. Susceptibility of Biomphalaria peregrina from Brazil and Ecuador to two strains of Schistosoma mansoni. Rev Inst Med Trop São Paulo. 1973;15 127-30.

[4] Caldeira RL, Teodoro TM, Gomes MFB, Carvalho OS. Preliminary studies investigating the occurrence of Biomphalaria cousini in Brazil. Mem Inst Oswaldo Cruz. 2010;105(4) 485-7.

[5] Carvalho OS, Rocha RS, Massara CL, Katz N. Expansão da esquistossomose mansoni em Minas Gerais. Mem Inst Oswaldo Cruz. 1987;82(Suppl. IV) 295-8.

[6] Carvalho OS, Massara CL, Rocha RS, Katz N. Esquistossomose Mansoni no Sudoeste do Estado de Minas Gerais (Brasil). Rev Saúde Pública. 1989;23 341-4.

[7] Carvalho OS, Massara CL, Silveira Neto HV, Guerra HL, Caldeira RL, Mendonça CLF, et al. Re-evaluation of Schistosomiasis Mansoni in Minas Gerais, Brazil. II. Alto Paranaiba Mesoregion. Mem Inst Oswaldo Cruz. 1997;92 141-2.

[8] WHO. Study Group on the Ecology of Intermediate Snail Hosts of Bilharziasis. Geneva: World Health Organization; 1957.

[9] Juberg P, Schall VT, Barbosa JV, Gatti MJ, Soares MS. Behavior of Biomphalaria glabra$t a$, the intermediate host snail of Schistosoma mansoni, at different depths in water in laboratory conditions. Mem Inst Oswaldo Cruz. 1987;82 179-208. 
[10] Katz N, Carvalho OS. Introdução recente da esquistossomose mansoni no sul do estado de Minas Gerais, Brasil. Mem Inst Oswaldo Cruz. 1983;78 281-4.

[11] Carvalho OS, Rocha RS, Massara CL, Katz N. Primeiros casos autóctones de esquistossomose mansonica em região do noroeste do Estado de Minas Gerais (Brasil). Rev Saúde Pública São Paulo. 1988;22 237-9.

[12] Carvalho MS, Pina MF, Santos SM. Conceitos Básicos de Sistemas de Informação Geográfica e Cartografia Aplicados à Saúde. Brasília: OPS/Ministério da Saúde, 2000.

[13] Rojas LI, Barcellos C, Petter P. Utilização de mapas no campo da epidemiologia no Brasil. Informe Epidemiológico do SUS. 1999;8 25-35.

[14] Cline BL. New eyes for epidemiologists: aerial photography and other remote sensing techniques. Am J Epidemiol. 1970;92 85-9.

[15] Beck LR, Lobitz BM, Wood BL. Remote Sensing and Human Health: New Sensors and New Opportunities. Emerg Infect Dis. 2000;6(3) 217-27.

[16] Raso G, Matthys B, N'Goran EK, Tanner M, Vounatsou P, Utzinger J. Spatial risk prediction and mapping of Schistosoma mansoni infections among schoolchildren living in western Côte d'Ivoire. Parasitology. 2005;131(01) 97-108.

[17] Cross ER, Bailey RC. Prediction of areas endemic for schistosomiasis through use of discriminant analysis of environmental data. Mil Med. 1984;149 28-30.

[18] Cross ER, Sheffield C, Perrine R, Pazzaglia G. Predicting areas endemic for schistosomiasis using weather variables and a Landsat data base. Mil Med.1984 Oct;149(10)542-4.

[19] Bavia ME, Hale L, Malone JB, Braud DH, Shane SM. Geographic information systems and the enviromental risk of Schistosomiasis in Bahia, Brazil. Am J Trop Med Hyg. 1999;60(4) 566-72.

[20] Chen S, Hu J. Geo-ecological zones and endemic diseases in China -- a sample study by remote sensing. Preventive Veterinary Medicine. 1991;11(3-4) 335-44.

[21] Malone JB, Huh OK, Fehler DP, Wilson PA, Wilensky DE, Holmes RA, et al. Temperature data from satellite imagery and distribution of schistosomiasis in Egypt. Am J Trop Med Hyg. 1994;51(3) 714-22.

[22] Cross ER, Newcomb WW, Tucker CJ. Use of weather data and remote sensing to predict the geographic and seasonal distribution of Phlebotomus papatasi in southwest Asia. Am J Trop Med Hyg. 1996;54(5) 530-6.

[23] Teles HMS. Distribuição de Biomphalaria straminea ao Sul da Região Neotropical, Brasil. Rev Saude Publica. 1996;30(4) 341-9.

[24] Kloos H, Fulford AJC, Butterworth AE, Sturrock RF, Ouma JH, Kariuki HC, et al. Spatial patterns of human water contact and Schistosoma mansoni transmission and infection in four rural areas in Machakos District, Kenya. Social Science \& Medicine. 1997;44(7) 949-68. 
[25] Malone JB, Abdel-Rahman MS, El Bahy MM, Huh OK, Shafik M, Bavia M. Geographic information systems and the distribution of Schistosoma mansoni in the Nile delta. Parasitol Today. 1997;13(3) 112-9.

[26] Gong P, Spear R, Seto E, Zhou Y, Xu B, Maxzle D, et al. Remote sensing and GIS for schistosomiasis control in Sichuan, China, an overview. Proceedings of Geoinformatics'99; 1999 19-21 JUNE; Ann Arbor, MI; 1999. p. 1-9.

[27] Lwambo NJS, Siza JE, Brooker S, Bundy DAP, Guyatt H. Patterns of concurrent hookworm infection and schistosomiasis in schoolchildren in Tanzania. Transactions of the Royal Society of Tropical Medicine and Hygiene. 1999;93(5) 497-502.

[28] Abdel-Rahman MS, El-Bahy MM, Malone JB, Thompson RA, El Bahy NM. Geographic information systems as a tool for control program management for schistosomiasis in Egypt. Acta Trop. 2001;79(1) 49-57.

[29] Bavia ME, Malone JB, Hale L, Dantas A, Marroni L, Reis R. Use of thermal and vegetation index data from earth observing satellites to evaluate the risk of schistosomiasis in Bahia, Brazil. Acta Trop. 2001;79(1) 79-85.

[30] Brooker S, Hay SI, Issae W, Hall A, Kihamia CM, Lwambo NJ, et al. Predicting the distribution of urinary schistosomiasis in Tanzania using satellite sensor data. Trop Med Int Health. 2001 Dec;6(12) 998-1007.

[31] Kristensen TK, Malone JB, McCarroll JC. Use of satellite remote sensing and geographic information systems to model the distribution and abundance of snail intermediate hosts in Africa: a preliminary model for Biomphalaria pfeifferi in Ethiopia. Acta Trop. 2001;79(1) 73-8.

[32] Malone JB, Yilma JM, McCarroll JC, Erko B, Mukaratirwa S, Zhou X. Satellite climatology and the environmental risk of Schistosoma mansoni in Ethiopia and east Africa. Acta Trop. 2001;79(1) 59-72.

[33] Zhou XN, Malone JB, Kristensen TK, Bergquist NR. Application of geographic information systems and remote sensing to schistosomiasis control in China. Acta Trop. 2001;79(1) 97-106.

[34] Beasley M, Brooker S, Ndinaromtan M, Madjiouroum EM, Baboguel M, Djenguinabe E, et al. First nationwide survey of th health of schoolchildren in Chad. Trop Med Int Health. 2002;7(7) 625-30.

[35] Brooker S. Schistosomes, snails and satellites. Acta Tropica. 2002;82(2) 207-14.

[36] Brooker S, Beasley M, Ndinaromtan M, Madjiouroum EM, Baboguel M, Djenguinabe $\mathrm{E}$, et al. Use of remote sensing and a geographic information system in a national helminth control programme in Chad. Bull World Health Organ. 2002;80 783-9.

[37] Brooker S, Hay SI, Tchuem Tchuenté LA, Ratard R. Using NOAA AVHRR data to model human helminth distribuitions in planning disease control in Cameroon. Photogrametric Engineering \& Remote Sensing. 2002;68(2) 175-9. 
[38] Davis GM, Wu WP, Chen HG, Liu HY, Guo J-G, Lin D-D, et al. A baseline study of importance of bovines for human Schistosoma japonicum infections around Poyang Lake, China: villages studied and snail sampling strategy. Am J Trop Med Hyg. 2002;66 359-71.

[39] Seto E, Xu B, Liang S, Gong P, Wu W, Davis GM, et al. The use of remote sensing for predictive modeling of schistosomiasis in China. Photogramm Eng Rem Sens. 2002;68(2) 167-74.

[40] Zhou X, Acosta L, Willingham AL, Leonardo LR, Minggang C, Aligui G, et al. Regional Network for Research, Surveillance and Control of Asian Schistosomiasis (RNAS). Acta Trop. 2002;82(2) 305-11.

[41] Zhou X, Dandan L, Huiming Y, Honggen C, Leping S, Guojing Y, et al. Use of landsat TM satellite surveillance data to measure the impact of the 1998 flood on snail intermediate host dispersal in the lower Yangtze River Basin. Acta Trop. 2002;82(2) 199-205.

[42] McNally K. Developing Risk Assessment Maps For Schistosoma Haematobium Based On Climate Grids And Remotely Sensed Data: Louisiana State University;2003.

[43] Barbosa CS, Araújo KC, Antunes L, Favre T, Pieri OS. Spatial distribution of schistosomiasis foci on Itamaracá Island, Pernambuco, Brazil. Mem Inst Oswaldo Cruz. 2004;99(Suppl. I) 79-83.

[44] Brooker S, Kabatereine NB, Clements ACA, Stothard JR. Schistosomiasis control. The Lancet. 2004;363 658-9.

[45] Kabatereine NB, Brooker S, Tukahebwa EM, Kazibwe F, Onapa AW. Epidemiology and geography of Schistosoma mansoni in Uganda: implications for planning control. Trop Med Int Health. 2004;9(3) 372-80.

[46] Nihei N, Kajihara N, Kirinoki M, Chigusa Y, Saitoh Y, Shimamura R, et al. Fixedpoint observation of Oncomelania nosophora in Kofu Basin--establishment of monitoring system of schistosomiasis japonica in Japan. Parasitology International. 2004;53 199-205.

[47] Xu B, Gong P, Biging G, Liang S, Seto E, Spear R. Snail Density Prediction for Schistosomiasis Control Using Ikonos and ASTER Images. Photogram Eng Rem S. 2004;70(11) 1285-94.

[48] Raso G, Vounatsou P, Singer BH, N'Goran EK, Tanner M, Utzinger J. An integrated approach for risk profiling and spatial prediction of Schistosoma mansoni - hookworm coinfection. PNAS. 2006;103(18) 6934-9.

[49] Guo J-G, Penelope V, Cao C-L, Jurg U, Zhu H-Q, Daniel A, et al. A geographic information and remote sensing based model for prediction of Oncomelania hupensis habitats in the Poyang Lake area, China. Acta Tropica. 2005;96(2-3) 213-22.

[50] Yang G-J, Vounatsou P, Zhou X-N, Tanner M, Utzinger J. A Bayesian-based approach for spatio-temporal modeling of county level prevalence of Schistosoma japoni- 
cum infection in Jiangsu province, China. International Journal for Parasitology. 2005;35(2) 155-62.

[51] Zhang Z-Y, Xu D-Z, Zhou X-N, Zhou Y, Liu S-J. Remote sensing and spatial statistical analysis to predict the distribution of Oncomelania hupensis in the marshlands of China. Acta Trop. 2005;96(2-3) 205-12.

[52] Brooker S, Alexander N, Geiger S, Moyeed RA, Stander J, Fleming F, et al. Contrasting patterns in the small-scale heterogeneity of human helminth infections in urban and rural environments in Brazil. International Journal for Parasitology. 2006;36(10-11) 1143-51.

[53] Freitas CC, Guimarães RJPS, Dutra LV, Martins FT, Gouvea EJC, Santos RAT, et al. Remote Sensing and Geographic Information Systems for the Study of Schistosomiasis in the State of Minas Gerais, Brazil. Geoscience and Remote Sensing Symposium, 2006 IGARSS 2006 IEEE International Conference on; 2006 July 31 2006-Aug. 4 2006; 2006. p. 2436-9.

[54] Gazzinelli A, LoVerde PT, Haddad JPA, Pereira WR, Bethony J, Correa-Oliveira R, et al. The spatial distribution of Schistosoma mansoni infection before and after chemotherapy in the Jequitinhonha Valley in Brazil. Mem Inst Oswaldo Cruz. 2006;101(Suppl. I) 63-71.

[55] Guimarães RJPS, Freitas CC, Dutra LV, Moura ACM, Amaral RS, Drummond SC, et al. Analysis and estimative of schistosomiasis prevalence for Minas Gerais state, Brazil, using multiple regression with social and environmental spatial data. Mem Inst Oswaldo Cruz. 2006;101(Suppl. I) 91-6.

[56] Tibiriçá SHC. Identificação morfológica e molecular, biometria, abundância e distribuição geográfica de Biomphalaria spp (Preston, 1910) (Mollusca, Planorbidae) no município de Juiz de Fora, Minas Gerais. MSc thesis.Universidade Federal de Juiz de Fora; 2006.

[57] Araújo KCGM, Resendes APC, Souza-Santos R, Silveira Júnior JC, Barbosa CS. Análise espacial dos focos de Biomphalaria glabrata e de casos humanos de esquistossomose mansônica em Porto de Galinhas, Pernambuco, Brasil, no ano 2000. Cadernos de Saúde Pública. 2007;23 409-17.

[58] Brooker S. Spatial epidemiology of human schistosomiasis in Africa: risk models, transmission dynamics and control. Trans R Soc Trop Med Hyg. 2007;101(1) 1-8.

[59] Matthys B, Tschannen AB, Tian-Bi NT, Comoé H, Diabaté S, Traoré M, et al. Risk factors for Schistosoma mansoni and hookworm in urban farming communities in western Côte d'Ivoire. Tropical Medicine \& International Health. 2007;12(6) 709-23.

[60] Moira AP, Fulford AJC, Kabatereine NB, Kazibwe F, Ouma JH, Dunne DW, et al. Microgeographical and tribal variations in water contact and Schistosoma mansoni exposure within a Ugandan fishing community. Tropical Medicine \& International Health. 2007;12(6) 724-35. 
[61] Clements ACA, Brooker S, Nyandindi U, Fenwick A, Blair L. Bayesian spatial analysis of a national urinary schistosomiasis questionnaire to assist geographic targeting of schistosomiasis control in Tanzania, East Africa. International Journal for Parasitology. 2008;38(3-4) 401-15.

[62] Guimarães RJPS, Freitas CC, Dutra LV, Moura ACM, Amaral RS, Drummond SC, et al. Schistosomiasis Risk Estimation in Minas Gerais State, Brazil, using Environmental Data and GIS techniques. Acta Trop. 2008;108 234-41.

[63] Martins FT. Mapeamento do risco da esquistossomose no estado de Minas Gerais, usando dados ambientais e sociais. MSc thesis. INPE; 2008.

[64] Yang K, Wang X-H, Yang G-J, Wu X-H, Qi Y-L, Li H-J, et al. An integrated approach to identify distribution of Oncomelania hupensis, the intermediate host of Schistosoma japonicum, in a mountainous region in China. International Journal for Parasitology. 2008;38(8-9) 1007-16.

[65] Zhang Z, Carpenter TE, Chen Y, Clark AB, Lynn HS, Peng W, et al. Identifying highrisk regions for schistosomiasis in Guichi, China: A spatial analysis. Acta Trop. 2008; 107 217-23.

[66] Clements ACA, Bosqué-Oliva E, Sacko M, Landouré A, Dembélé R, Traoré M, et al. A Comparative Study of the Spatial Distribution of Schistosomiasis in Mali in 1984-1989 and 2004-2006. PLoS Negl Trop Dis. 2009;3(5) e431.

[67] Guimarães RJPS, Freitas CC, Dutra LV, Felgueiras CA, Moura ACM, Amaral RS, et al. Spatial distribution of Biomphalaria mollusks at São Francisco River Basin, Minas Gerais, Brazil, using geostatistical procedures. Acta Trop. 2009;109 181-6.

[68] Guimarães RJPS, Freitas CC, Dutra LV, Felgueiras CA, Drummond SC, Oliveira G, et al. Use of Indicator Kriging to Investigate Schistosomiasis in Minas Gerais State, Brazil. J Trop Med. 2012;2012(Article ID 837428) 10.

[69] Martins-Bedé FT, Godo L, Sandri S, Dutra LV, Freitas CC, Carvalho OS, et al. Classification of Schistosomiasis Prevalence Using Fuzzy Case-Based Reasoning. Bio-Inspired Systems: Computational and Ambient Intelligence: Berlin/Heidelberg, 2009. p8.

[70] Zhang Z, Clark AB, Bivand R, Chen Y, Carpenter TE, Peng W, et al. Nonparametric spatial analysis to detect high-risk regions for schistosomiasis in Guichi, China. Transactions of the Royal Society of Tropical Medicine and Hygiene. 2009;103(10) 1045-52.

[71] Carvalho OS, Scholte RGC, Guimarães RJPS, Freitas CC, Drummond SC, Amaral RS, et al. The Estrada Real project and endemic diseases: the case of schistosomiasis, geoprocessing and tourism. Mem Inst Oswaldo Cruz. 2010;105(4) 532-6.

[72] Galvão AF, Favre TC, Guimarães RJPS, Pereira APB, Zani LC, Felipe KT, et al. Spatial distribution of Schistosoma mansoni infection before and after chemotherapy with two praziquantel doses in a community of Pernambuco, Brazil. Mem Inst Oswaldo Cruz. 2010;105(4) 555-62. 
[73] Guimarães RJPS, Freitas CC, Dutra LV, Scholte RGC, Amaral RS, Drummond SC, et al. Evaluation of a linear spectral mixture model and vegetation indices (NDVI and EVI) in a study of schistosomiasis mansoni and Biomphalaria glabrata distribution in the state of Minas Gerais, Brazil. Mem Inst Oswaldo Cruz. 2010;105(4) 512-8.

[74] Guimarães RJPS, Freitas CC, Dutra LV, Scholte RGC, Martins-Bedé FT, Fonseca FR, et al. A geoprocessing approach for studying and controlling schistosomiasis in the state of Minas Gerais, Brazil. Mem Inst Oswaldo Cruz. 2010;105(4) 524-31.

[75] Martins-Bedé FT, Dutra LV, Freitas CC, Guimarães RJPS, Amaral RS, Drummond SC, et al. Schistosomiasis risk mapping in the state of Minas Gerais, Brazil, using a decision tree approach, remote sensing data and sociological indicators. Mem Inst Oswaldo Cruz. 2010;105(4) 541-8.

[76] Schur N, HürSchur N, Stensgaard A, Chimfwembe K, Mushinge G, Simoonga C, et al. Spatially explicit Schistosoma infection risk in eastern Africa using Bayesian geostatistical modeling. Acta Trop. 2011. In Press. http://dx.doi.org/10.1016/j.actatropica. 2011.10.006

[77] Stensgaard A-S, Utzinger J, Vounatsou P, Hürlimann E, Schur N, Saarnak CFL, et al. Large-scale determinants of intestinal schistosomiasis and intermediate host snail distribution across Africa: Does climate matter? Acta Trop. 2011. In Press. http:// dx.doi.org/10.1016/j.actatropica.2011.11.010

[78] Sturrock HJW, Gething PW, Ashton RA, Kolaczinski JH, Kabatereine NB, Brooker S. Planning schistosomiasis control: investigation of alternative sampling strategies for Schistosoma mansoni to target mass drug administration of praziquantel in East Africa. International Health.3(3) 165-75.

[79] TibiriçaSHC, Mittherofhe A, Castro MF, Lima AC, Gonçalves M, Pinheiro IO, et al. Malacological survey of Biomphalaria snails in municipalities along the Estrada Real in the southeast of theState of Minas Gerais, Brazil. Rev Soc Bras Med Trop. 2011;44(2) 163-7.

[80] Neter J, Kutner MH, Nachtssheim CJ, Wasserman W. Applied linear statistical models. Boston: WCB/McGraw-Hill, 1996.

[81] Assunção RM, Neves MC, Camara G, Freitas CC. Efficient regionalization techniques for socio-economic geographical units using minimum spanning trees. Int J Geogr Inf Sci. 2006;20 797-811.

[82] INPE. SPRING V.4.1 Sistema de Processamento de Informações Georeferenciadas http://www.dpi.inpe.br/spring/. 2005. 
(C) 2013 The Author(s). Licensee IntechOpen. This is an open access article distributed under the terms of the Creative Commons Attribution 3.0 License, which permits unrestricted use, distribution, and reproduction in any medium, provided the original work is properly cited. 